\title{
Poly(3-methylthiophene-co-3-octylthiophene) Based Solid-State Photoelectrochemical Device
}

\author{
Tesfalidet Lemma and Teketel Yohannes* \\ Department of Chemistry, Addis Ababa University, P. O. Box 1176, Addis Ababa, Ethiopia
}

\begin{abstract}
O copolímero, poli(3-metiltiofeno-co-3-octiltiofeno), foi sintetizado eletroquimicamente a partir de mistura de 3-metiltiofeno e 3-octiltiofeno. Foi construída e estudada uma célula fotoeletroquímica do estado sólido (CFE) utilizando as melhores condições de formação do copolímero. A célula foto-eletroquímica continha material foto-ativo poli(3-metiltiofeno-co-3octiltiofeno), poli(3MT-co-3OT), vidro recoberto com óxido de estanho dopado com índio (OEI), poli(óxido de etileno) amorfo, (POEA), eletrólito polimérico condutor complexado com o par redox $\mathrm{I}_{3}^{-} / \mathrm{I}^{-}$e um poli(3,4-etilenodioxitiofeno) polimerizado eletroquimicamente (PEDOT) sobre OEI como um contra-eletrodo. Sob iluminação de $100 \mathrm{~mW} \mathrm{~cm} \mathrm{~cm}^{-2}$ aproximadamente, foi obtida uma voltagem de circuito aberto de $165 \mathrm{mV}$ e corrente de curto-circuito de $0.21 \mu \mathrm{A} \mathrm{cm}{ }^{-2}$. A eficiência de conversão da corrente-fóton monocromático incidente (IPCE\%) para iluminação frontal foi igual a 0.51 (OEI/PEDOT) e 0.15 para iluminação de fundo, considerando o comprimento de onda de $460 \mathrm{~nm}$. Além disso, foram estudadas a dependência da corrente de curto-circuito com a voltagem de circuito aberto em relação à intensidade da luz e ao tempo de iluminação.
\end{abstract}

The copolymer, poly(3-methylthiophene-co-3-octylthiophene), was electrochemically synthesized from a mixture of 3-methylthiophene and 3-octylthiophene. Once the best condition for the copolymer formation was obtained a solid-state photoelectrochemical cell (PEC) was constructed and studied. The PEC contains the photoactive material poly(3-methylthiopheneco-3-octylthiophene), poly(3MT-co-3OT), coated on indium doped tin oxide (ITO) coated glass, an amorphous poly(ethylene oxide), POMOE, an ion conducting polymer electrolyte complexed with $\mathrm{I}_{3}^{-} \mathrm{I}^{-}$redox couple and an electrochemically polymerized poly(3,4-ethylenedioxythiophene) (PEDOT) coated on ITO-coated glass as a counter electrode. An open-circuit voltage of 165 $\mathrm{mV}$ and a short circuit current of $0.21 \mu \mathrm{A} \mathrm{cm}^{-2}$ were obtained with light illumination of approximately $100 \mathrm{~mW} \mathrm{~cm}{ }^{-2}$. Incident monochromatic photon-to-current conversion efficiency (IPCE\%) of 0.51 for front side (ITO/PEDOT) illumination and 0.15 for backside (ITO/poly(3MTco-3OT)) illumination at wavelength of $460 \mathrm{~nm}$ were obtained. In addition, dependence of the short circuit current and open circuit voltage on light intensity and time of illumination were studied.

Keywords: electrochemical copolymerization, solid-state photoelectrochemical cell, poly(3methylthiophene-co-3-octylthiophene), amorphous poly(ethylene oxide), $\mathrm{I}_{3}^{-} / \mathrm{I}^{-}$redox couple

\section{Introduction}

Solar energy is one of the promising renewable sources of energy when the supply of the conventional energy sources, such as coal, petroleum, and natural gas, gets depleted. Energy from the sun is not only available in plentiful supply, but also introduces no direct contamination of the environment. As a result considerable research work has been aimed at harnessing solar energy.

*e-mail: teketely@yahoo.com; tekeyoha@chem.aau.edu.et
Conjugated polymers having semiconductor as well as conductor-like behavior have become the most promising materials for use in electrochromic devices, ${ }^{1}$ electrode catalysis, ${ }^{2,3}$ electrochemomechanical devices, ${ }^{4}$ modified electrodes, ${ }^{5}$ photovoltaics, ${ }^{6}$ corrosion protection ${ }^{7}$ etc. Conducting polymers do not only function in a similar manner to the inorganic semiconductors and conductive metals but also have important advantages such as: low cost, light weight, ease of fabrication, the possibility of large area coatings and environmental stability.

The demands for using conducting polymers as photoactive electrodes are increasing due to several 
reasons such as development of easy ways of processing conjugated polymers, high absorption coefficients of these materials and the possibility of designing the electrodes through molecular engineering. Solar power conversion efficiencies as high as $5 \%$ have been reported from bulk heterojunction solar photovoltaic cells consisting of donor semiconducting polymers and acceptor fullerene derivatives. ${ }^{8}$ Further improvements appear possible by extending the spectral coverage, by enhancement of the mobility of charge carriers, and by removing sources of instability.

A number of studies have been reported in the literature on the photoelectrochemical properties of conjugated conducting polymers, such as polyaniline, ${ }^{9,10}$ polypyrrole, ${ }^{11}$ poly(3-methylthiophene) ${ }^{12}$ and PEDOT. ${ }^{13}$ Among the conjugated conducting polymers, poly(heterocycles) containing alkylthiophene units constitute an important class of materials because of their chemical stability, high electrical conductivity, and solubility in common organic solvents. Recently solid state PECs based on conducting polymers and polymer electrolytes have been developed and studied. ${ }^{14}$ Although the efficiencies were found to be low, these types of PECs avoid the problems associated with liquid electrolytebased PECs such as photocorrosion, side reactions, and packaging that limit the working life of such cells.

Modification of the form, structure, and properties of a conducting polymer is mandatory to meet the specific requirements for different technological applications. The selection of the proper method of modification depends on both the desired property and the level at which the modification will occur. Copolymerization is one method of modification and results in materials with properties intermediate between the individual polymers. Many types of copolymers have been prepared by chemical and electrochemical polymerization from mixtures of different monomers. ${ }^{15-17}$ The various possible copolymers differ by the mode of polymerization (chemical or electrochemical), and by the structure of the obtained copolymers (random or block). ${ }^{17}$

Poly(3-methylthiophene) and poly(3-octylthiophene) are conducting polymers which have been the subject of extensive investigation due to high conductivity, good environmental stability, fair stability under irradiation and reliable mechanical adhesion to different electrodes. At present there are few commercial applications of conducting polymers due to their non-processibility, instability in the doped or neutral state, or/and sensitivity to ambient air or water. The processibility, high stability in both neutral and doped states and the high optical absorption spectrum of the random copolymer poly(3-methylthiophene-co3-octylthiophene), indicates that such copolymer may be of great practical importance for opto-electronic devices. Therefore, we report herein the first studies made on a solid-state PEC based on electrochemically synthesized copolymer of 3OT and 3MT, [poly(3octylthiophene-co-3-methylthiophene)], on ITO as a photoactive electrode; an amorphous poly(ethylene oxide), POMOE, complexed with $\mathrm{I}_{3}{ }^{-} / \mathrm{I}^{-}$redox couple as a polymer electrolyte and an electrochemically polymerized poly(3,4-ethylenedioxythiophene), PEDOT, on ITO as a counter electrode.

\section{Experimental}

3-Methylthiophene and 3-octylthiophene were obtained from Aldrich. All polymerization and copolymerization experiments were carried out in a threeelectrode one-compartment electrochemical cell with platinum foil counter electrode, $\mathrm{Ag} / \mathrm{Ag}^{+}$quasi-reference electrode and indium doped tin-oxide (ITO) coated glass working electrode. The ITO-coated glass substrates were cleaned successively with distilled water, acetone, and ethanol and dried with an air gun. The monomer solutions contained $0.1 \mathrm{~mol} \mathrm{~L}^{-1} 3$-octylthiophene and $0.2 \mathrm{~mol} \mathrm{~L}^{-1}$ 3-methylthiophene in $0.1 \mathrm{~mol} \mathrm{~L}^{-1} \mathrm{LiClO}_{4}$-acetonitrile solutions. Various volume ratios of the two monomers were used in the polymerization solution to identify the optimum ratio for the copolymer formation. The polymerization and the copolymerization were carried out potentiostatically resulting in a conducting film. Copolymer formation was also studied in a fixed monomer mixture with volume ratio of $0.1 \mathrm{~mol} \mathrm{~L}^{-1} 3$-octylthiophene: $0.2 \mathrm{~mol} \mathrm{~L}^{-1} 3$-methylthiophene of $4: 5$ and varying the polymerization potential systematically between $1.5 \mathrm{~V}$ and $2.0 \mathrm{~V}$.

Once the best condition for the copolymer formation was worked out, the photoactive electrode was obtained by electropolymerzation from $0.1 \mathrm{~mol} \mathrm{~L}^{-1} 3 \mathrm{OT}$ and 0.2 mol L $\mathrm{L}^{-1} 3 \mathrm{MT}$ on ITO-coated glass. The copolymerization was carried out potentiostatically at $+1.6 \mathrm{~V}$ versus $\mathrm{Ag} /$ $\mathrm{Ag}^{+}$quasi-reference electrode at which potential the ITO electrode surface becomes covered with a blue doped polymer film. The electrochemical cell was then washed several times with acetonitrile and finally filled with a monomer-free solution of $0.1 \mathrm{~mol} \mathrm{~L}^{-1} \mathrm{LiClO}_{4}$ in acetonitrile to reduce the copolymer to its neutral semiconducting state at $-0.5 \mathrm{~V}$. The reduced form of the copolymer was red in colour and was rinsed with acetonitrile and dried in air. On the top of electrochemically copolymerized poly(3MT-co-3OT), a film of 
the polymer electrolyte (POMOE) complexed with $\mathrm{I}_{3}^{-/ I^{-}}$ redox couple was solvent cast from methanol solution. The redox couple $\mathrm{I}_{3}^{-} / \mathrm{I}^{-}$was prepared by dissolving 47.4 $\mathrm{mg} \mathrm{KI}$ and $7.2 \mathrm{mg} \mathrm{I}_{2}$ in $25 \mathrm{ml}$ of methanol separately. Similarly, $304.2 \mathrm{mg}$ of POMOE was dissolved in $25 \mathrm{~mL}$ of methanol. Finally, equal volumes of each solution were mixed to produce polymer electrolyte complexed with the redox couple. The mole ratio of oxygen to potassium calculated by taking into account both the oxymethylene and oxyethylene oxygen atoms was 25 and the mole ratio of $\mathrm{KI}$ to $\mathrm{I}_{2}$ was 10 , i.e., the concentration of $\mathrm{I}_{2}$ was onetenth the concentration of KI. The PEC was completed by contacting with an oxidized PEDOT, electrochemically polymerized on ITO-coated glass, which is used as a counter electrode. The solution used for polymerization contained $0.2 \mathrm{~mol} \mathrm{~L}^{-1}$ 3, 4-ethylenedioxythiophene, EDOT (Bayer) in $0.1 \mathrm{~mol} \mathrm{~L}^{-1} \mathrm{LiClO}_{4}$ in acetonitrile. The polymerization was carried out potentiostatically at 1.8 $\mathrm{V}$ for five seconds at which potential the electrode surface became covered with a thin transparent blue conducting film. Contact between the electrodes was then ensured by the application of pressure by a spring attached to a sample holder. The PEC was then mounted in a sample holder inside a metal box having a $1 \mathrm{~cm} \times 1 \mathrm{~cm}$ light entrance window, which determined the illumination area. All experiments were carried out at ambient temperature of about $20^{\circ} \mathrm{C}$.

An electrochemical analyzer (IJ Cambria Scientific Model CHI600A) was used to measure and record the current-voltage response both in the dark and under illumination. The photocurrent generated and photovoltage produced, by turning illumination on and off, were also recorded. The PEC was illuminated with $250 \mathrm{~W}$ tungstenhalogen lamp regulated by an Oriel power supply (Model 66182). The white light intensity was measured by a Luxmeter (Model LX-101). Monochromatic light was obtained with an Oriel grating monochromatic (Model 77250) introduced into the light path and scanned manually. All spectra were corrected for the spectral response of the lamp and monochromator by normalization to the response of a calibrated silicon photodiode (Hamamatsu, Model S1336-8BK) placed in the sample position. Optical absorption measurements were carried out by Perkin Elmer Lambda 19 UV/VIS/NIR spectrometer.

\section{Results and Discussion}

\section{Electrochemical characterization of the copolymer}

To determine the proper conditions for electropolymerization, we first examined the polymerization potentials of 3MT and 3OT. The onset polymerization potentials on ITO electrode were determined to be 1.6 $\mathrm{V}$ and $1.4 \mathrm{~V}$ versus $\mathrm{Ag} / \mathrm{Ag}^{+}$quasi-reference electrode for 3MT and 3OT, respectively. Therefore, a potential of $1.6 \mathrm{~V}$, which is not too high to over-oxidize, was selected for the potentiostatic polymerization and copolymerization. The poly(3MT-co-3OT) film was electrochemically characterized by cyclic voltammetry in $0.1 \mathrm{~mol} \mathrm{~L}^{-1} \mathrm{LiClO}_{4}$-acetonitrile solution in the absence of the monomers. The cyclic voltammogram of poly(3MT-co-3OT) and cyclic voltammogram of the homopolymers, P3MT and P3OT are shown in Figure 1. If the prepared copolymers were mixtures of P3MT and P3OT, two pairs of anodic/cathodic peaks should have appeared at different potentials due to each of them.

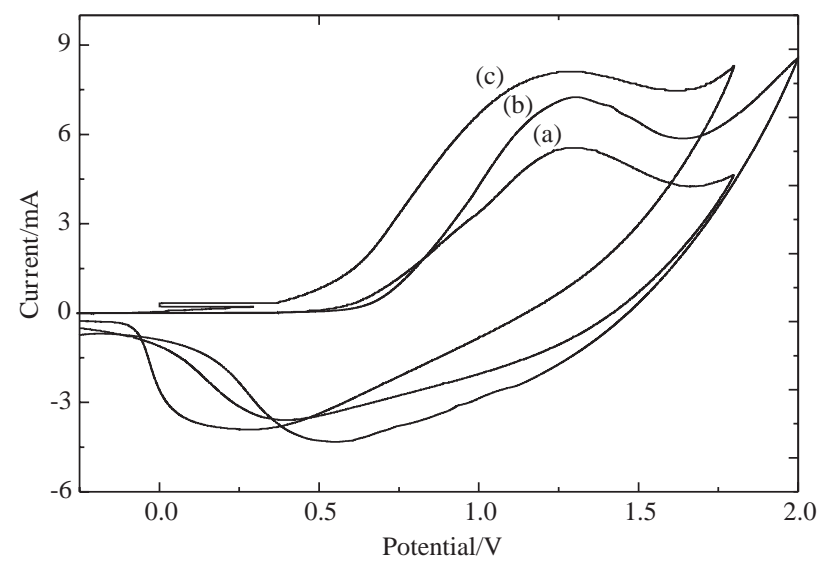

Figure 1. Cyclic voltammogram of (a) $0.2 \mathrm{~mol} \mathrm{~L}^{-1} 3 \mathrm{MT}$ (b) poly(3MT-co3OT ) obtained from a volume ratio of 4:5 $\left(0.1 \mathrm{~mol} \mathrm{~L}^{-1} 3 \mathrm{OT}: 0.2 \mathrm{~mol} \mathrm{~L}^{-1}\right.$ 3MT) (c) $0.1 \mathrm{~mol} \mathrm{~L}^{-1} 3 \mathrm{OT}$, with ITO working electrode, Pt foil counter electrode, $\mathrm{Ag} / \mathrm{Ag}^{+}$quasi reference electrode, and monomer-free $0.1 \mathrm{~mol} \mathrm{~L}^{-1}$ $\mathrm{LiClO}_{4}$-acetonitrile electrolyte. Scan rate is $100 \mathrm{mV} \mathrm{s}^{-1}$.

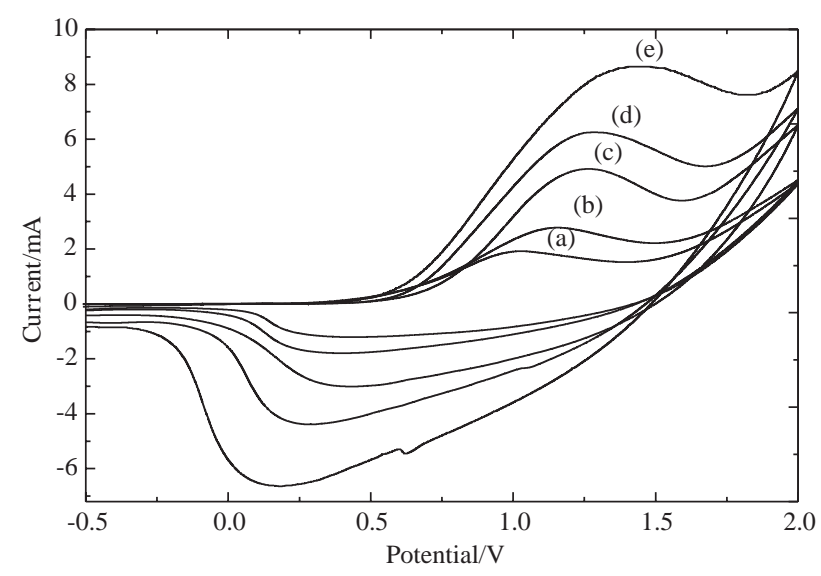

Figure 2. Cyclic voltammograms of poly(3MT-co-3OT ) obtained from a volume ratio of $4: 5\left(0.1 \mathrm{~mol} \mathrm{~L}^{-1} 3 \mathrm{OT}: 0.2 \mathrm{~mol} \mathrm{~L}^{-1} 3 \mathrm{MT}\right)$ at different electrochemical polymerization potentials : (a) $1.5 \mathrm{~V}$ (b) $1.6 \mathrm{~V}$ (c) $1.7 \mathrm{~V}$ (d) $1.8 \mathrm{~V}$ (e) $2.0 \mathrm{~V}$, with ITO working electrode, Pt foil counter electrode, $\mathrm{Ag} / \mathrm{Ag}^{+}$quasi reference electrode, and monomer-free $0.1 \mathrm{M} \mathrm{LiClO}_{4}-\mathrm{ac}-$ etonitrile electrolyte. Scan rate is $100 \mathrm{~m} \mathrm{~V} \mathrm{~s}^{-1}$. 
In a fixed monomer mixture with a volume ratio of $0.1 \mathrm{~mol} \mathrm{~L}^{-1}$ 3OT:0.2 $\mathrm{mol} \mathrm{L}^{-1} 3 \mathrm{MT}$ of 4:5 the polymerization potentials were systematically varied between $1.5 \mathrm{~V}$ and $2.0 \mathrm{~V}$, expecting the resulting copolymer may have different ratios of each component in the copolymer.

The cyclic voltammograms of the copolymers generated at different potentials are shown in Figure 2. It is therefore possible to conclude that the composition of the film can easily be changed by changing the polymerization potential without any change in the concentration of each monomer in the electrolyte solution, and it is also possible to change systematically the composition of the monomers in the copolymer produced.

\section{Solid State PEC device characterization}

\section{Current-voltage characteristics}

Current-voltage curve for the solid-state PEC, recorded in the dark and under white light illumination with a light intensity of about $100 \mathrm{~mW} \mathrm{~cm}{ }^{-2}$ from the front side (ITO/ PEDOT side) of the PEC, is shown in Figure 3. An opencircuit voltage of $165 \mathrm{mV}$ and a short-circuit current of $0.21 \mu \mathrm{A} \mathrm{cm}^{-2}$ were obtained.

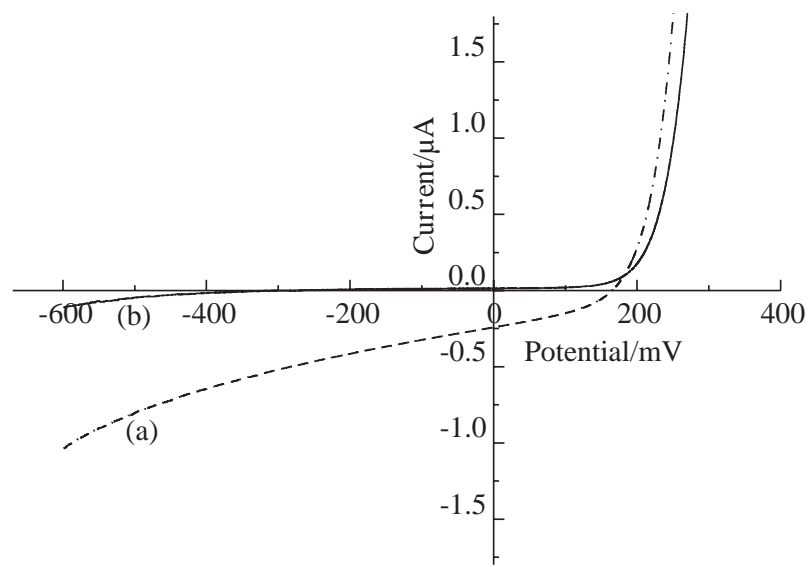

Figure 3. I-V curves of solid-state PEC based on poly(3-MT-co-3OT) (a) under illumination through the front side with a light intensity of 100 $\mathrm{mW} \mathrm{cm}^{-2}$ and (b) in dark.

The light irradiated onto the PEC generates excitons which diffuse to the poly (3MT-co-3OT) / redox polymer electrolyte junction where they will be separated by the electric field created at the interface due to the difference in the electrochemical potential. The electrons generated travel towards the electrolyte where they react with triiodide to produce iodide. On the other hand, the holes move into the bulk of poly (3MT-co-3OT) and then travel through the external load to the counter electrode where they oxidize the iodide to triiodide.
Time dependence of short circuit current and open circuit voltage

The short circuit current and open circuit voltage induced by periodically blocking the light path to the sample are depicted in Figures 4 and 5, respectively. When the light is switched on, the photocurrent rises to steady state value of $0.21 \mu \mathrm{A} \mathrm{cm}^{-2}$ and when switched off it decays at approximately the same rate to zero current. The open circuit voltage increased immediately when the PEC was illuminated from the front side, reaching a steady state value of $170 \mathrm{mV}$. When the light was blocked, the open circuit voltages decreased slowly to a dark potential of 20 $\mathrm{mV}$.

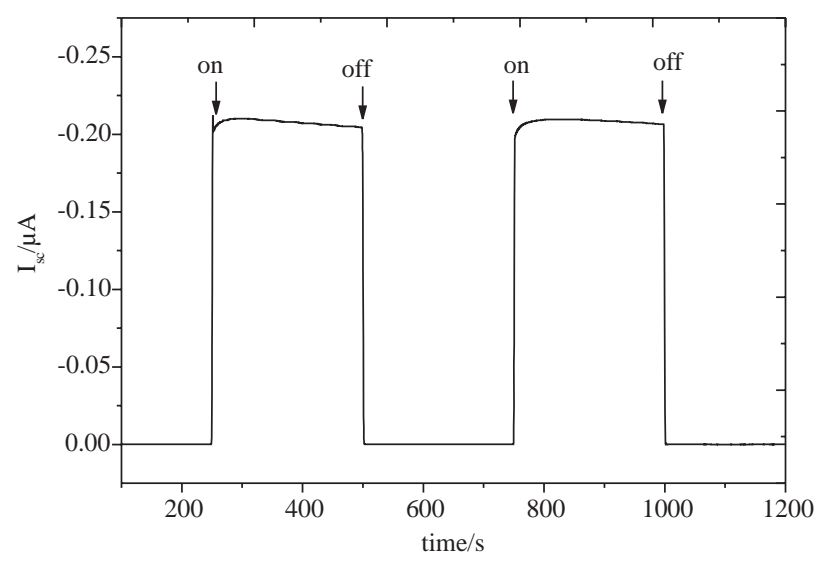

Figure 4. $I_{\mathrm{sc}}$ changes induced by turning illumination on and off from the front side of the solid-state PEC based on poly(3-MT-co-3OT) with a light intensity of $100 \mathrm{~mW} \mathrm{~cm}^{-2}$.

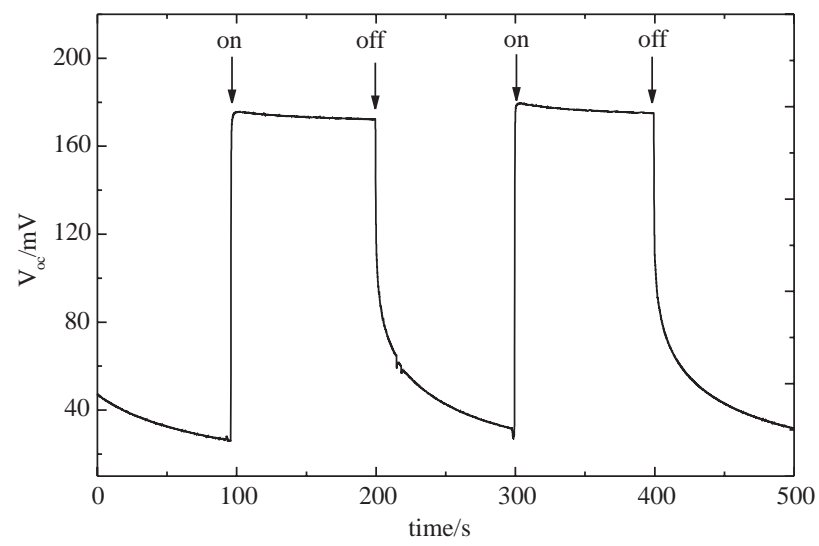

Figure 5. Photovoltage response to switching illumination on and off from the front side of the solid-state PEC based on poly(3-MT-co-3OT) with a light intensity of $100 \mathrm{~mW} \mathrm{~cm}^{-2}$.

\section{Spectral response}

Figure 6 displays the photocurrent action spectra of the solid-state PEC in which monochromatic light was incident from the front side (Figure 6a), and 
backside (Figure 6(b)). The incident monochromatic photon-to-current conversion efficiencies (IPCE \%), obtained at wavelength of $460 \mathrm{~nm}$, were $0.51 \%$ for front side and $0.15 \%$ for backside illumination, respectively.

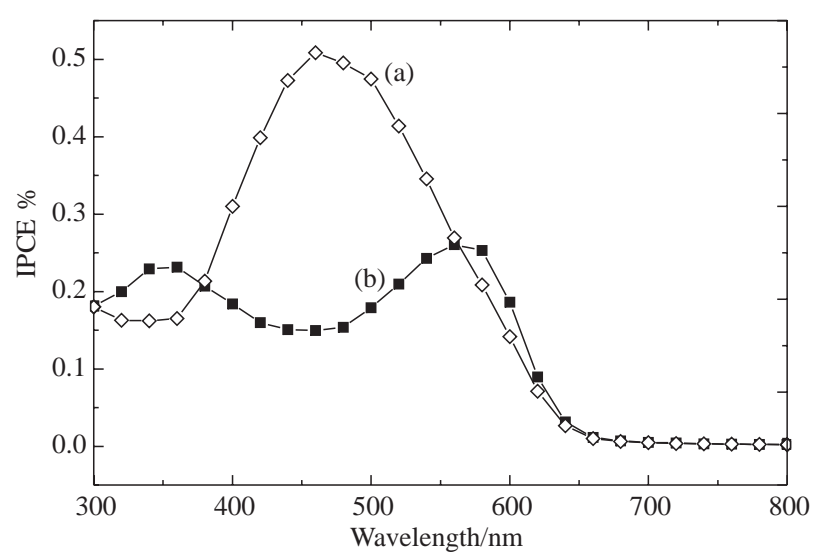

Figure 6. Photocurrent action spectra for solid-state PEC based on poly(3MT-co-P3OT) illuminated through (a) front side and (b) back side.

For characterizing the junction properties, action spectra and optical absorption spectra were compared. The action spectra obtained by illumination through the front side matched with the absorption spectrum (Figure 7) while the action spectrum obtained with backside illumination did not match. The correspondence of the action spectrum with the optical absorption spectrum when illuminated from the front side indicated that the junction responsible for the photocurrent generation was that between poly(3MT-co3OT) and the redox polymer electrolyte.

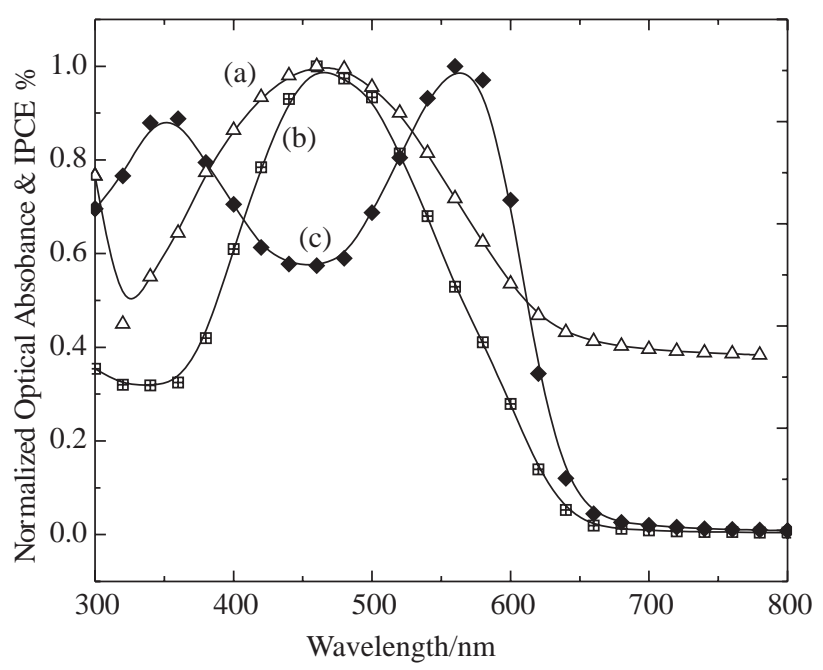

Figure 7. (a) Normalized optical absorption spectrum of poly(3MT-co3OT), (b) Normalized photocurrent action spectrum from front side illumination, and (c) Normalized photocurrent action spectrum for back side illumination of poly(3MT-co-3OT) based solid-state PEC.
The difference in the IPCE\% values, obtained for front side and backside, is a clear indication that the polymer film thickness is greater than the width of the average active region; consequently, only the exictons that are able to diffuse into the Schottky barrier region contribute to free carrier generations. In this case the excitons (electron-hole pairs) created by illuminating from the front (rectifying) side, can easily reach the active junction and dissociate into free carriers. For this reason, the action spectrum obtained for front side illumination resembles the absorption spectrum of the copolymer. However, most of the excitons generated by illumination at the ITO/ poly(3MT-co-3OT) side will either recombine or be trapped during diffusion through the polymer layer towards the Schottky barrier. Therefore for backside illumination the polymer acts as a filter and the action spectrum of the device resembles the inverse of the absorption spectrum of the polymer. At lower and higher wavelengths the IPCE from backside is greater than that from front side. This is because for backside illumination, when the absorption constant is high (at the wavelength of maximum absorbance), the excitons will be generated very close to the ITO on which the photoactive polymer film has been deposited. Therefore, fewer numbers of excitons will reach the polymer/polymer electrolyte interface. As a result the photocurrent will be less. On other hand at lower and higher wavelengths (i.e. where the absorption constants are low), only weakly absorbed photons penetrate into the depletion region and the excitons will be generated much closer to the polymer/polymer electrolyte interface with major contribution to the photocurrent.

\section{Dependence of $I_{s c}$ and $V_{o c}$ on incident light intensity}

For Schottky-type organic and inorganic solar cells, the short-circuit current increases with increasing light intensity, ${ }^{18}$ while the open-circuit voltage varies logarithmically with incident light intensity. ${ }^{19}$ The dependence of the short-circuit current and open-circuit voltage on the incident light intensity $\left(\mathrm{I}_{\mathrm{i}}\right)$ are depicted in Figure 8 and 9, respectively.

The slope of the plot for $\log \mathrm{I}_{\mathrm{sc}}$ versus $\log \mathrm{I}_{\mathrm{i}}$ is 0.73 . Such sublinear dependence of $\log \mathrm{I}_{\mathrm{sc}}$ on $\log \mathrm{I}_{\mathrm{i}}$ indicates the presence of exciton recombination due to surface states that act as recombination centers. On the other hand, the photovoltage dependence on $\log \mathrm{I}_{\mathrm{i}}$ displays the usual semilogarthimic dependence expected for Schottky junction solar cells. 


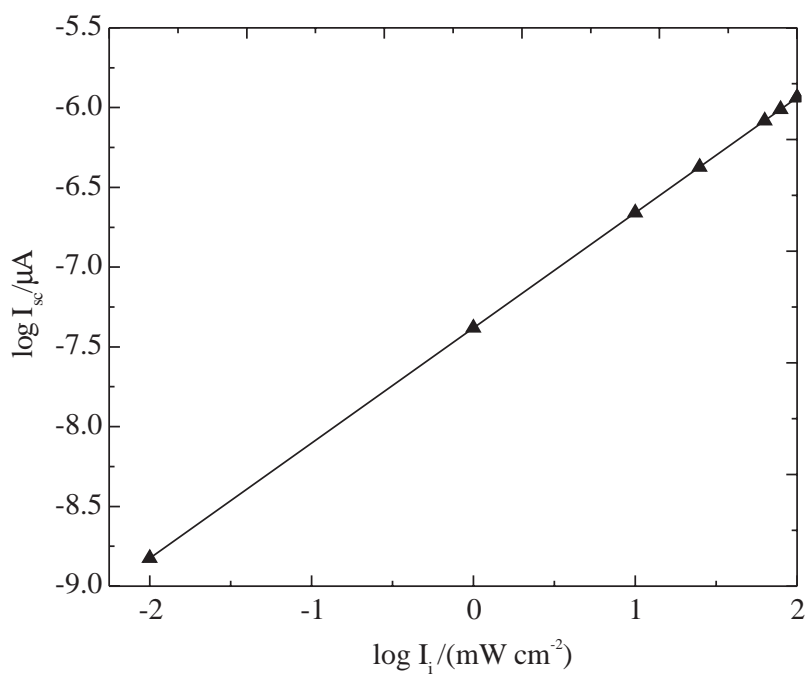

Figure 8. Dependence of $I_{s c}$ on incident light intensity for illumination through the front side.

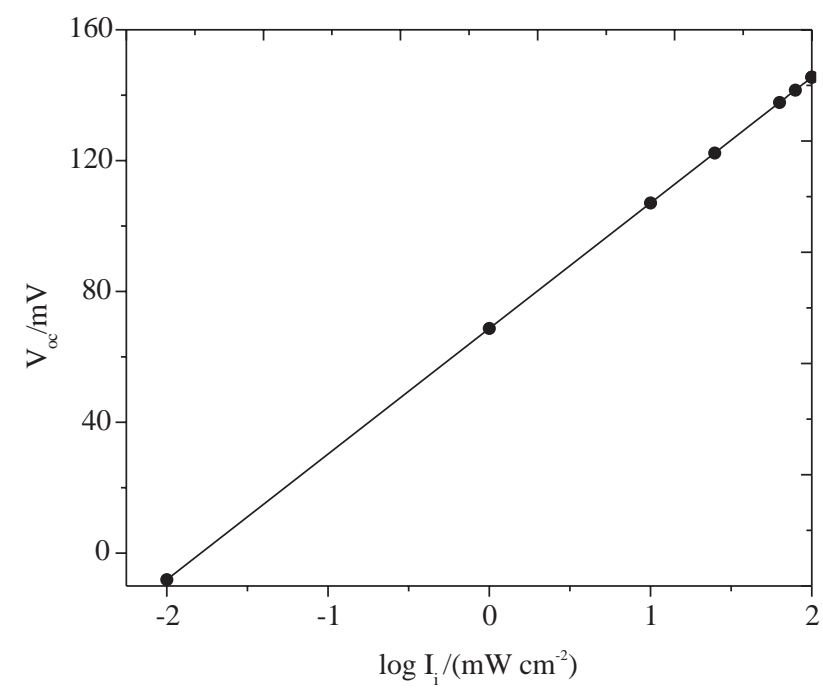

Figure 9. Dependence of $\mathrm{V}_{\mathrm{oc}}$ on logarithm of incident light intensity for illumination through the front side.

\section{Conclusions}

In this study a copolymer of 3MT and 3OT was prepared by electrochemical polymerization. Using this copolymer a solid-state PEC was constructed and studied. The open-circuit voltage and the short-circuit current obtained for the cell were $165 \mathrm{mV}$ and $0.21 \mu \mathrm{A} \mathrm{cm}^{-2}$, respectively at illumination intensity of $100 \mathrm{~mW} \mathrm{~cm}^{-2}$. The external quantum efficiencies obtained from the front side (ITO/PEDOT) and backside (ITO/ poly(3MT-co-3OT) illumination were $0.51 \%$ and $0.15 \%$, respectively at 460 $\mathrm{nm}$. The limiting step for photocurrent generation is still that of exciton dissociation and collection of the resulting carriers, as observed from the study of the short-circuit current on incident light intensity.

\section{Acknowledgments}

The authors thank the Research and Publications Office of the Addis Ababa University, the Ethiopian Science and Technology Commission and the Third World Academy of Sciences, Trieste, Italy, for financial support.

\section{References}

1. De Paoli, M.-A.; Casalbore, G.; Girotto, E.; Gazotti, W.; Electrochimica Acta 1999, 44, 2983.

2. Malinauskas, A.; Synth. Met. 1999, 107, 75.

3. Kros, A; Stephan W. F.; Van Hövell, M.; Nico A. J. M.; Sommerdijk; Nolte Roeland, J. M. ; Adv. Mater. 2001, 20, 1550.

4. Onoda, M.; Oshiyuki kato, Y.; Shonaka, H.; Tada, K.; Electr. Eng. Jpn 2004, 149, 120.

5. Roy, P.; Sudan, M.; Takeyoshi, S.; Gil, O.; Fujishima, P. A.; Ohsakaa, T.; Electroanalysis 2004, 16, 1777.

6. Yu, G.; Heeger, A. J.; J. Appl. Phys. 1995, 78, 4510.

7. Tuyen, P.; Nguyen, E.; Rammelt, U.; Plieth, W.; J. Solid State Electrochem. 2003, 7, 497.

8. Shrotriya , V; Li ,G.; Huang, J.; Yao, Y.; Moriarty, T.; Emery, K.; Yang, Y.; Nature 2005, 4, 864 ; Ma, W.; Yang, C.; Gong, X.; Lee, K.; Heeger, A.; Adv. Funct. Mater. 2005, 15, 1617; Reyes, M.R.; Kim, K.; Carroll, D.L.; Appl. Phys. Lett. 2005, 87, 083506, 1.

9. Neves, S.; De Paoli, M. -A.; Genies, E. M.; Synth. Met. 1994, 68, 91.

10. Maia, D. J.; Neves, S.; Alves, O. L.; De Paoli, M. -A.; Electrochim. Acta 1999, 44, 1945.

11. Miquelino, F. L. C.; De Paoli, M.-A.; Genies, E. M.; Synth. Met. 1994, 68, 91.

12. Micaroni, L.; De Paoli, M.-A.; Sol. Energy Mater. Sol . Cells 1996, 46, 79.

13. Girotto, E. M.; Gazotti, W. A.; De Paaoli, M.-A.; J. Phys. Chem. B 2000, 104, 6124.

14. Gazotti, W. A.; Nogueira, A. F.; De Paoli, M.-A.; Sol. Energy Mater. Sol Cells 2001, 69, 315; Yohannes ,T.; Solomon, T.; Inganäs, O.; Synth. Met. 1996, 82, 215; Yohannes, T.; Inganäs, O.; J. Electrochem. Soc. 1996, 143, 2310; Yohannes, T.; Inganäs, O.; Sol. Energy Mater. Sol. Cells 1998, 51, 193; Yohannes, T.; Inganäs, O.; Synth. Met. 1999, 107, 97. Mosissa, A.; Yohannes, T.; Solomon, T.; Sol. Energy Mater. Sol. Cells, 2004, 83, 301.

15. Pei, Q.; Inganäs, O.; Synth. Met. 1992, 46, 353.

16. Pei, Q.; Inganäs, O.; Polymer 1993, 34, 247.

17. Yohannes, T; Carlberg, J. C; Inganäs, O.; Solomon, T; Synth. Met. 1997, 88, 15.

18. Gutmann, F.; Lyons, L. E.; Organic Semiconductors, Wiley: New York, 1967.

19. Meier, H.; Organic Semiconductors, Verlag Chemie: Berlin, 1974.

Received: November 8, 2006 Web Release Date: July 13, 2007 